\title{
La Salada Characters
}

\author{
IN LA SALADA \\ Bolivian Family
}

PABLO: older son and manager of the family business. He has also opened up a stall in Mendoza selling "Adidas" jackets.

BEATRIZ: migrant, Pablo's mother. She plays an active role, always suggesting ideas for fabrics and accessories, especially when the new season is approaching and new products have to be developed.

EUSEBIO: migrant, Pablo's father. Together with Pablo, he migrated first in order to learn how to manufacture clothing.

MARTíN: Pablo's younger brother. He is usually at the stall and helps out during the production process.

MARIELA: Pablo's younger sister. Matías taught her field hockey at the very beginning of the fieldwork.

\section{Manufacturers and Stallholders}

LEO: stallholder neighbor of Pablo. He manufactures children's caps.

MATILDE and NORBERTO: husband-and-wife team that manufacture at home and sell aprons at La Salada.

JULIETA: makes women's underwear. Starting with no capital, she took leftover scraps of material from other Bolivian producers. 
FELIPE: previously owned a car business that he lost in the 2001 financial crash. His stall is positioned at the main entrance of a leading shed market. He manufactures and sells children's clothing.

JUAN MANUEL: one of Felipe's sons. Felipe wants to open a further stall for him.

OSVALDO: together with his wife, he manufactures and sells "Gap" clothing in one leading shed market.

BETINA: manufactures and sells jackets for security staff.

\section{Cart-Pullers, Warehouse Owners, Squatters, and Money Collectors}

MICKY: flamboyant warehouse owner who answers in metaphors. Likes to sit on the bench outside his warehouse watching the passersby.

GRACIELA: single mother who "owns" several stalls mounted on the streets.

VALERIA: used to be a shed-market collector. She is now an influential political broker.

EMILIO: a former "owner" of street stalls.

ESPERANZA: used to "own" several street stalls and defend her property armed.

ALEJO: experienced cart-puller working for the Urkupiña shed market. Used to fight for payment in cash or bags of vegetables at Central Market. Later sold flowers and spent the money on drugs before becoming a cart-puller.

SILVINA: Alejo’s wife.

DANIEL: cart-puller and former gang member with a history of committing armed robbery and using the money to fund a serious drug habit. Now a born-again Christian. 
ÁLVARO: chief of security at one of the shed markets. He previously worked for Argentina's secret service during the military dictatorship.

\section{Sweatshop Workers (Only)}

JAVI: migrant from the Argentine province Jujuy. He sells his skills as a buttonhole maker and ironer.

CÉSAR: Peruvian immigrant specialized in cutting fabrics.

CHEPITA: Bolivian migrant. She has a sweatshop and provides sewing services for La Salada garment manufacturers.

MÓNICA: Bolivian migrant. She was recruited in Bolivia through kinship networks and exploited in sweatshops. She no longer works in the garment industry.

\section{BETWEEN LA SALADA AND POLITICS}

HORACIO: influential local politician whose father was mayor of the district.

JORGE PALACIO: manager of one of La Salada's three shed markets.

ADRIÁN: Palacio's right-hand man.

CHARLIE: ex-chief of the National Gendarmerie. He is now in charge of the security of one shed market.

SEBASTIÁN: personal advisor to Moreno, Argentina's secretary of commerce.

MORENO: Argentine secretary of commerce.

WILSON: was the right-hand man of a shed-market manager. He now works as the mayor's advisor and a political broker. 


\section{OUTSIDE LA SALADA}

ARMANDO: "legal" garment manufacturer with financial troubles. $\mathrm{He}$ manufactured Argentina's 1986 World Cup shirt. 